ARTIGO ORIGINAL

ISSN 1677-5090

(C) 2019 Revista de Ciências Médicas e Biológicas

DOI: http://dx.doi.org/10.9771/cmbio.v1i1.31996

\title{
Cellular changes diagnosed by cérvico-vaginal cytology in a public health laboratory of Teresina-PI
}

\author{
Alterações celulares diagnosticadas por meio da citologia cervico-vaginal no \\ laboratório de saúde pública de Teresina-PI
}

\begin{abstract}
Sabryna Coelho Teixeira ${ }^{1}$, Gisele Lopes Cavalcante ${ }^{2}$, Sergio Ricardo Pereira Brandim3, Maria Camila Leal de Moura ${ }^{4}$, Yara Maria da Silva Pires ${ }^{5}$, Paulo Pedro do Nascimento6*

${ }^{1}$ Farmacêutica Pela Faculdade Integral Diferencial; ${ }^{2}$ Graduada em Farmácia Faculdade Integral Diferencial; ${ }^{3}$ Graduada em Farmácia pela Universidade Federal do Piauí. Farmacêutico Bioquímico; ${ }^{4}$ Graduanda em Farmácia no Centro Universitário Santo Agostinho; ${ }^{5}$ Farmacêutica. Mestre em Farmacologia pela Universidade Federal do Piauí; ${ }^{6}$ Mestre em Farmacologia Clínica pela Universidade Federal do Ceará. Professor da disciplina Citologia Clínica da Universidade Federal do Piauí.
\end{abstract}

\begin{abstract}
Objective: to verify the frequency of cellular alterations of the female genital tract of women assisted by a public clinical laboratory in Teresina - Piaui in 2016, as well as to evaluate the relation between patients' education levels and the frequency of atypia found. Methodology: data from the 9040 forms of cervical-vaginal oncocytology (SUS standard) from the 2016 year were collected. Results: 9040 reports were analyzed, among which 8,095 (89.55\%) had negative and $945(10.45 \%)$ were positive to oncologic abnormalities. It was identified squamous cells of indeterminate significance with $5.84 \%$, low-grade intraepithelial lesions (LSIL) with 1,97\%, high-grade intraepithelial lesions (HSIL) 1.33\%, glandular cell atypia (ACG) with 1.25\% and invasive squamous cell carcinoma $0.06 \%$. Regarding the level of schooling, women who attended elementary and high school corresponded to the higher percentage of patients. Conclusion: it is concluded that the incidence of atypia was considerably higher than described in the previous literature. Thus, it is recommended the adoption of strategies to improve the adherence and the awareness of the population regarding the necessity of this exam. Keywords: Papanicolaou. Cervical inflammations. Lesion.
\end{abstract}

\begin{abstract}
Resumo
Objetivo: verificar a frequência das alterações celulares do trato genital feminino que acometeram mulheres atendidas no ano de 2016 em um laboratório clínico público em Teresina-PI, avaliar a frequência dos níveis de escolaridade das pacientes e correlacionar com a frequência das atipias encontradas. Metodologia: os dados foram coletados a partir das fichas de requisição de exame citopatológico do colo do útero (padrão SUS), referentes ao ano de 2016. Resultados: dos 9040 laudos analisados, 8.095 (89,55\%), tiveram citologia negativa para as alterações oncológicas e 945 (10,45\%) foram positivos. Estes ficaram assim distribuídos: células escamosas de significado indeterminados com 5,84\%, as lesões intra-epiteliais de baixo grau (LSIL) com 1,97\%, lesões intra-epiteliais de alto grau (HSIL) com 1,33\%, atipias de significado indeterminado em células glandulares (ACG) com 1,25\% e carcinoma epidermóide invasor com $0,06 \%$. No que se refere ao grau de escolaridade, maior frequência foi observada entre pacientes que frequentaram o ensino fundamental e médio. Conclusão: os resultados permitiram concluir que a incidência das atipias foi muito além das observadas na literatura. Para equacionar esse problema, o país deve adotar estratégias que visem a adesão e a conscientização da população sobre a necessidade do exame.
\end{abstract}

Palavras-chave: Papanicolau. Inflamações cérvico-vaginais. Lesão.

\section{INTRODUCTION}

In the last years, the microscopic morphology of pathological alterations, especially cancer, has been thoroughly investigated. The Greek-American George N. Papanicolaou and the pathologist Aureli Babes were the first to observe and to report cancerous cells in vaginal and cervical smears (GOMPEL; KOSS, 2006). The Brazilian Ministry of Health indicates the Papanicolaou test to women aged 25-60 and to sexually active younger women (BUENO, 2008; CALDERÓN; CAMPOS, 2019).

Correspondente/Corresponding: *Paulo Pedro do Nascimento - Faculdade Integral Diferencial - End: Rua Veterinário Bugyja Brito, 1354 - Horto, Teresina-PI-Tel: (86) 98149-3150-E-mail: ppfarmaco@globo.com
Cancer of the uterine cervix (CUC) is one of the most common malignant diseases of women, which begins with precursor lesions that can progress to become invasive cancers. Its development can be prevented by cytology screening and appropriate treatment. According to the Brazilian Ministry of Health (BRASIL, 2011), cervical screening is the most cost-effective method for detecting precursor lesions of CUC. In addition, Papanicolaou test plays an important role to determine inflammatory cell changes and other vaginal infections (NAYAR; WILBUR, 2018), which are designated as reactive cellular alterations by the Bethesda cytological system. Thus, this test allows evaluating the intensity of inflammatory alter- 
ations, as well as to follow its evolution and, in certain cases, to determine the causal agent (GOMPEL; KOSS, 2006; SOLOMON NAYAR, 2005).

Cervical neoplasms are cellular changes strongly related: lifetime number of sexual partners, use of oral contraceptives, smoking habits, among others. These risk factors are also associated with the increase of Sexual Transmitted Infections (STIS), such as Human Papilloma Virus (HPV), which is considered the main agent that causes these cell changes (BUENO, 2008; GOMPEL, KOSS, 2006, GUARISI et al., 2004, MENDONÇA et al., 2008).

However, there are relevant changes at the cellular level which are precursors of CUC as well, such as atypia and lesions. The category of atypical squamous cells of undetermined significance (ASCUS) is subdivided in ASC-US, which has undetermined significance, and $\mathrm{ASC}-\mathrm{H}$, which cannot exclude high grade squamous intraepithelial lesion (FERNANDES et al., 2012); and Glandular cell atypia (AGC) (PRADO et al., 2012). Besides, the lesions are divided into low-grade squamous intraepithelial lesions (LSIL) and high grade squamous intraepithelial lesions (HSIL) (UCHIMURA et al., 2012).

The consequences of cervical malignant disorders, as high deaths rates, stimulate this investigation of the incidence of cellular atypia of the cervix. Thus, in order to contribute for the epidemiological studies, this article aims to verify the frequency of microbiological agents and cellular atypia of the female genital tract in women assisted by a clinical laboratory in Teresina - Piaui in 2016, as well as evaluate their level of education.

\section{METHODOLOGY}

The research respects the ethical principles established by Resolution 196/96 of the National Health Council. It was submitted and approved by the Human Research Ethics Committee of the Faculdade Integral Diferencial (FACID) of DeVry Brazil group protocol no 18307614.7.0000.5211.

This is a retrospective, cross sectional and descriptive study. Data from the 9040 Application Forms of Cervical-Vaginal Oncocytology (SUS standard) were collected from January to December 2016 in a Public Health Laboratory in the city of Teresina, Brazil. It was analyzed: Frequency of atypia; cases of squamous cell carcinoma by age; cases of cellular cervical atypia by age; types of microorganisms; and education level of patients.

The data were organized on Microsoft Office Excel ${ }^{\circledR}$ 2010, followed by statistical analyses through Statistical Package for the Social Sciences (SPSS 20.0) and expressed in graphs and tables.

\section{RESULTS}

To perform this study, 9040 cytopathological exams of a reference clinical analysis laboratory in the city of Teresina - Piaui were analyzed. It was observed that 8095 (89.55\%) did not have any oncologic alterations, howev- er 945 (10.45\%) were classified as positive to oncologic abnormalities.

According with the frequency of atypia in Table 1, it is observed that the category of ASCUS was the most prevalent, with 529 cases (5.84\%) equivalent of its subcategories: ASC-US representing 4.7\% (426) of the analyzed reports and the ASC-H with 1.14\% (103). Also, it is observed LSIL with 178 cases (1.97\%); HSIL with 119 cases (1.33\%); atypical glandular cells of undetermined significance (AGC), including those possibly non-neoplastic and not able to rule out high-grade intraepithelial lesions, with 113 cases (1.25\%) and invasive squamous cell carcinoma (ISCC), with 06 cases (0.06\%).

Analyzing the relation of ages with cases of squamous cell carcinoma, it was found only one single case in the age group 40-44 years and 05 cases among the following groups: 55-59 (2), 60-64 (1), and 65-69 years (2).

Table 1 - Frequency of atypia of cytology reports in the year of 2016 in Teresina - Piaui, Brazil.

\begin{tabular}{lcc}
\hline \multicolumn{1}{c}{ DIAGNOSIS } & $\boldsymbol{n}$ & $\boldsymbol{\%}$ \\
\hline Negative & 8.095 & 89,55 \\
ASCUS* & 529 & 5,84 \\
LSIL & 178 & 1,97 \\
HSIL & 119 & 1,33 \\
AGC & 113 & 1,25 \\
ISCC & 06 & 0,06 \\
TOTAL & 9.040 & 100 \\
\hline
\end{tabular}

${ }^{*}$ ASCUS $=$ ASC-US + ASC-H.

For a better understanding, the percentages of cervical atypia by age groups are described in Graph 1. The most frequent age group was 30-34 years with 134 $(14,29 \%)$, followed by $35-39(12,28 \%)$ and $25-29$ years $(12,17 \%)$.

Graph 1 - Percentage of cellular cervical atypia by age group of women's clinical reports in Teresina, Piaui in 2016. (O eixo das ordenadas (eixo y) não deixa claro o que quer dizer $2,4,6 \ldots$ sugiro fazer uma escala de $10 \mathrm{em} 10$ ou $20 \mathrm{em} 20$ onde o eixo $Y$ deixe claro a quantidade de casos descritos).

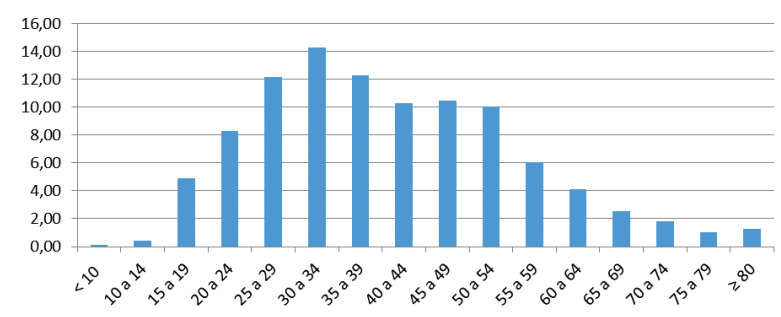

Regarding the microbiological agents, the cocci showed the highest occurrence, corresponding to $58.3 \%$ 
of the cases, followed by the lactobacillus with $29 \%$ (Graph 2).

Graph 2 - Microorganisms identified in cytopathological exam of patients in a clinical laboratory in Teresina, Piaui in 2016.

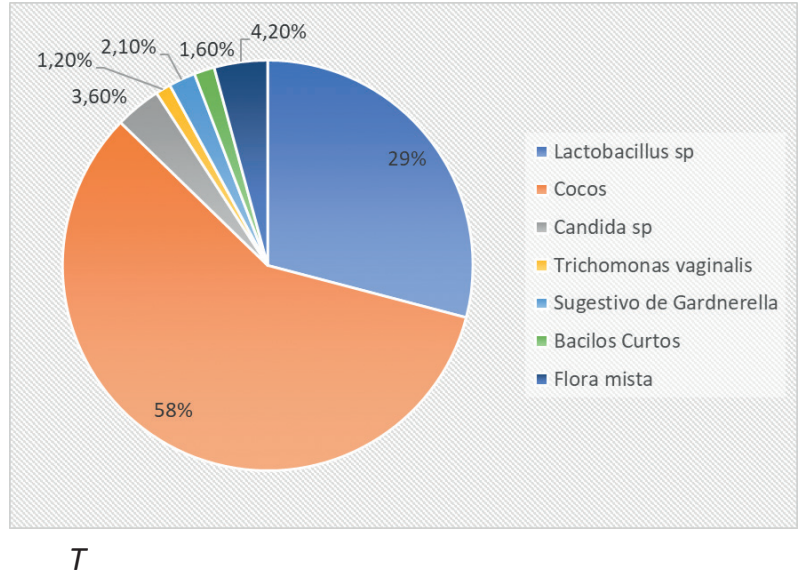

able 2 shows the level of education of patients, in which is possible to observe that $666(7.4 \%)$ cytological re- ports corresponded to non-literate women; 2182 (24.2\%) complete elementary school, while 2565 (28.3\%) did not. Moreover, 2486 (27.5\%) have high school diploma; 481 (5.3\%) attend to College. 660 (7.3\%) reports did not inform the level of education.

Table 2 - Education level of patients of cytopathological exam in a clinical laboratory of Teresina, Piauí in 2016.

\begin{tabular}{lrc}
\hline \multicolumn{1}{c}{ LEVEL OF EDUCATION } & N & \% \\
\hline Not informed & 660 & 7,3 \\
Non-literate & 666 & 7,4 \\
Not completed elementary school & 2.565 & 28,3 \\
Completed elementary school & 2.182 & 24,2 \\
High school & 2.486 & 27,5 \\
College & 481 & 5,3 \\
TOTAL & 9.040 & 100 \\
\hline
\end{tabular}

Table 3 correlates atypia with the education level. The higher incidence of total atypia is observed among women who attended elementary and high school.

Table 3 - Atypia according the education level of patients of a clinical laboratory of Teresina - PI in 2016.

\begin{tabular}{|c|c|c|c|c|c|c|c|}
\hline \multirow[b]{2}{*}{ ATYPIA } & \multicolumn{6}{|c|}{ EDUCATION LEVEL } & \multirow[b]{2}{*}{ Total } \\
\hline & Not informed & Non-literate & $\begin{array}{c}\text { Elementary } \\
\text { school } \\
\text { (incomplete) }\end{array}$ & $\begin{array}{c}\text { Elementary } \\
\text { school } \\
\text { (completed) }\end{array}$ & $\begin{array}{c}\text { High } \\
\text { School }\end{array}$ & College & \\
\hline ASC-US & 62 & 41 & 119 & 86 & 97 & 21 & 425 \\
\hline ASC-H & 10 & 9 & 29 & 25 & 23 & 7 & 103 \\
\hline AGC & 11 & 7 & 38 & 24 & 28 & 4 & 112 \\
\hline LSIL & 15 & 6 & 42 & 52 & 54 & 8 & 177 \\
\hline HSIL & 11 & 6 & 37 & 36 & 30 & 1 & 121 \\
\hline $\begin{array}{l}\text { Invasive squamous cell } \\
\text { carcinoma }\end{array}$ & 3 & 1 & 2 & 0 & 0 & 0 & 6 \\
\hline TOTAL & 112 & 70 & 267 & 223 & 232 & 41 & 945 \\
\hline
\end{tabular}

DISCUSSION

The oncologic positive results are higher than expected by the National Program to Combat Cancer of the Uterine Cervical, of the Brazilian Ministry of Health, which classifies the normal percentage around $4 \%$. For the Bethesda System, the cases with cytological alterations should represent 4-6\% of total cases (SALOMON; NAYAR, 2018).

Regarding the prevalence of the type of lesions, it was verified that the percentage of ASCUS (5.85\%) was elevated. According to recommendations of Bethesda System, the number of ASCUS should represent a maximum of 5\% of the total number of cases analyzed in a laboratory, and it should not be higher than two to three times the number of LSIL cases. These indicators are parameters used in the routine quality control of a cytopathological laboratory, because the high percentages of undetermined atypia may suggest issues either in the sample, in the laboratory analysis or in both phases (BUENO, 2008; FERNANDES et al., 2012).

According to Bueno (2008), the possibility of determining ASCUS as a diagnostic generates many controversies and discussions, because it is common to use this category as escape for the diagnostic difficulties and it is difficult to establish treatments.

In the last years, the diagnosis of AGC has increased considerably. It probably happened due to the improvement of cytologists' training, in addition to the advance of smear collection techniques, and the increase in cases of glandular lesions. The prevalence of these atypia (Table 1) agrees with previous studies, which determinate that the incidence ranges from $0.1 \%$ to $2.1 \%$ (MARQUES et al., 2011).

Squamous intraepithelial lesions can be a consequence of active human papillomavirus (HPV) infection and abnormal cell changes, which represent high-grade precursors to invasive cancer. These abnormalities are 
divided into LSIL and HSIL (SOLOMON; NAYAR, 2005). The frequency of LSIL (1.97\%) identified in the population analyzed (Table 1), corresponds to previous reports of the Brazilian literature that indicates incidence range of $0.42 \%-2.0 \%$ (DOS SANTOS et al., 2013). According to INCA (2011), the most severe squamous cell atypia is represented by HSIL, which present a bigger proportion of the thickness of the epithelium composed of undifferentiated cells. In addition, HSIL has a higher probability to progress to cervical cancer.

Invasive squamous cell carcinoma is considered an invasive cervical tumor. Müller and Maziero (2010) reported its incidence into two peaks: one from 30-40 years and the other after menopause. These data corroborate the age groups of higher incidences of invasive squamous cell carcinoma found in this study.

It has been observed that there is a clear association of cervical lesions with age. As shown in Graph 1, the frequency of atypia was higher in the groups from 25 to 39 years. The number of patients with atypia in these age groups reflects those of the general population. This shows that the cervical cancer screening policy is being followed, and this policy prioritizes the age group between 25 and 64 years - a population at risk to develop cervical cancer. As these people are sexually active, this age group is more susceptible to such alterations, according to different authors (GUARISI et al. 2004; MENDONÇA et al., 2008).

Moreover, the results corroborate the research of Fredrich and Renner (2019), in which Cocci were the predominant species, followed by Lactobacillus sp. According to Silvestre (2016), Papanicolaou test has been used secondarily in the detection of microorganisms. It is observed that some agents that cause female genital discharge can be identified by this technique, such as Gardnerella vaginalis (the main cause of bacterial vaginosis), Candida $s p$. and Trichomonas vaginalis.

Moreover, demographic characteristics and sexual habits can be related to the prevalence of genital infections, thus, it can justify the microorganism variability found in this study. Soares and Silva (2010) reported that the proportion of pathogens causing vaginitis and/ or vaginosis varies by location. Thus, depending on the region, the presence of Gardnerella vaginalis can vary $2.9 \%$ to $21.8 \%$, as well as Candida sp (2.4\% to $24 \%)$, with corroborating our result. The authors also reported that Trichomonas vaginallis ranges from $1.4 \%$ to $4.49 \%$, this value is similar to our results (1.2\%).

Several studies regarding the Brazilian population have shown that women with higher education were more likely to take the cytology test, compared to women with lower education (AMORIM; BARROS, 2014). According to Table 2, the number of both non-literate women and patients highly educated (college) were not statistically significant. In addition, it is possible to see that women who attended elementary and high school are prevalent.

The literature states that cervical-vaginal cell atypia and cervicitis are often associated to socioeconomic fac- tors, such as adequate sexual education and schooling, which are reflected in attitudes associated with poor hygiene habits, a high number of partners, lack of condom use and other protective behaviours (OLIVEIRA et al., 2007).

Therefore, understanding the social determinants of health is essential to affirm the real reasons that lead women to seek healthcare service. Pearson's comparative analysis did not show a linear relation between the atypia and the level of schooling of the patients, presenting a correlation coefficient of only 0.062 . However, analyzing the data of Table 3, it can be observed that the women who had not completed elementary school present a higher incidence of atypia, except for LSIL, which was higher in women who attended high school.

\section{CONCLUSION}

The incidence of atypia was considerably higher than described in the literature. It was observed that the most prevalent atypia was ASCUS followed by LSIL. Regarding the educational level, the higher incidence of total atypia was observed among women who attended elementary and high school. The prevalence of microbiological agents agreed with previous studies. Thus, it is recommended the adoption of strategies of health promotion designed to improve cytopathological care.

\section{REFERENCES}

AMORIM, V.M.S.L.; BARROS, M.B.A. Equity of access to Pap smears: population-based study in Campinas, São Paulo, Brazil. Rev. bras. epidemiol., São Paulo, v. 17, supl. 2, p. 136-149, 2014.

BRASIL. Instituto Nacional do Câncer. Diretrizes Brasileiras para o Rastreamento do Câncer do Colo do Útero. Rio de Janeiro: INCA, 2011. Disponivel em: http://www1.inca.gov.br/inca/Arquivos/Titulos/ Nomenclatura_colo_do_utero.pdf. Acesso em: 22 mar. 2016.

BUENO, K. S. Atipias escamosas de significado indeterminado: novas qualificações e importância na conduta clínica. RBAC, Rio de Janeiro, $v$. 40, n. 2, p. 121-128, maio 2008. Disponível em: http://www.sbac.org.br/ pt/pdfs/rbac/rbac_40_02/09.pdf. Acesso em: 10 mar. 2013.

BRENNA S. M. F. et al. Conhecimento, atitude e prática do exame de Papanicolaou em mulheres com câncer de colo uterino Knowledge, attitudes, and practices related to the Pap smear among women. Cad. saúde pública, Rio de Janeiro, v.17, n.4, p. 909-914, jul./ago. 2001. Disponivel em: http://www.scielosp.org/pdf/csp/v17n4/5296.pdf. Acesso em: 14 mar. 2014

COSTA, J. M. M. Prevalência das lesões precursoras do câncer do colo do útero. 2013. 81p. Trabalho de Conclusão de Curso (Graduação em Medicina) - Faculdade Integral Diferencial, Teresina, 2013.

DOS SANTOS, J.C. et al. Ocorrência de papilomavírus humano na cérvice uterina de mulheres da região ocidental da Amazônia Brasileira. Acta Amazonica, v. 43, n. 2, p. 185-190, 2013.

FERNANDES, F. et al. Diagnóstico Citopatológico de ASC-US e ASC-H no Serviço Integrado Tecnológico em Citologia do INCA. Rev. bras. cancerol., Rio de Janeiro, v. 58, n.3, p. 453-559, 2012. Disponivel em: : http://www.inca.gov.br/rbc/n_58/v03/pdf/15_artigo_diagnostico_citopatologico_asc_us_asc_h_servico_integrado_tecnologico_citologia_inca.pdf. Acesso em: 08 abr.2014. 
GUARISI, R. et al. Rastreamento diagnóstico e tratamento das lesões precursoras e do câncer invasor de colo uterino no município de Franco da Rocha, SP. Rev. bras. cancerol., Rio de Janeiro, v. 50, n. 1, p.7-1, fev. 2004. Disponível em: http://www.inca.gov.br/rbc/n_50/v01/pdf/ARTIGO1.pdf. Acesso em: 09 mar. 2013.

GOMPEL, C.; KOSS, G.L. Introdução à citopatologia ginecológica com correlações histológicas e clínicas. São Paulo: Roca, 2006.

CALDERÓN, J. E. S.; CAMPOS, A. S. Effectiveness of diagnostic testing for Cervical Cancer and Human Papilloma Virus. JONNPR, [s.I], v.4, n.5, p.551-66, 2019.

MARQUES, J. P. H. et al. Células glandulares atípicas e câncer de colo uterino: revisão sistemática. Rev. Assoc. Med. Bras., São Paulo, v.57, n.2, p.234-238, 2011. Disponível em: http://www.scielo.br/pdf/ramb/ v57n2/v57n2a24.pdf. Acesso em: 14 abr.2013.

MÜLLER G. C.; MAZIERO C. Alterações citológicas: uma revisão sobre a importância da Citologia Oncótica. Unoesc \& Ciência - ACBS, Santa Catarina, v. 1, n. 2, p. 87-94. 2010. Disponivel em: http:// editora.unoesc.edu.br/index.php/acbs/article/view/579. Acesso em: 23 abr. 2013.

MENDONÇA, V. G. et al. Mortalidade por câncer do colo do útero: características sociodemográficas das mulheres residentes na cidade de Recife, Pernambuco. Rev. Bras. Ginecol. Obstet, Rio de Janeiro, v. 30 , n.5, p. 248-255, abr. 2008. Disponivel em: http://www.scielo.br/pdf/ rbgo/v30n5/a07v30n5.pdf. Acesso em: 10 mar. 2013.

NAYAR, R; WILBUR, D.C. Sistema Bethesda para relato de citologia cervical. Definições, critérios e notas explicativas. 3. ed. São Paulo: Livraria Livromed, 2018.

OLIVEIRA, A. B. et al. Prevalência de gardnerella e mobiluncus em exames de colpocitologia em Tome-Açu, Pará. Rev. para. med., Belém, v. 21, n.4, p. 47-51. 2007. Disponivel em: http://scielo.iec.pa.gov.br/pdf/ rpm/v21n4/v21n4a08.pdf. Acesso em: 22 abr. 2013.
PRADO, P. R. et al. Caracterização do perfil das mulheres com resultado citológico ASCUS/AGC, LSIL e HSIL segundo fatores sociodemográficos, epidemiológicos e reprodutivos em Rio Branco-AC, Brasil. Rev. bras. cancerol., Rio de Janeiro, v. 58, n. 3, p. 471-479, 2012.

FREDRICH, E. K.; RENNER, J. D. P. Cervical cytopathological changes in Pap smear test in the city of Santa Cruz do Sul, Rio Grande do Sul, Brazil. J. Bras. Patol. Med. Lab., Rio de Janeiro, v. 55, n. 3, p. 246-257, Jun., 2019.

SILVA, H. A. et al. Papilomavírus humano e lesões intra-epiteliais cervicais: estudo colpocitológico retrospectivo. RBAC, Rio de Janeiro, v. 35, $n$. 3, p. 117-121, jul.2003. Disponível em: bases.bireme.br/cgi-bin/wxislind. exe/iah/online. Acesso em: 08 mar. 2013.

SILVEIRA, L.M.S.; CRUZ A.L.N.; FARIAS M.S. Atipias cervicais detectadas pela citologia em mulheres atendidas em dois hospitais da rede pública de São Luiz - MA. RBAC, Rio de Janeiro, v. 40, n.2, p. 115-119, 2008. Disponivel em: http://www.sbac.org.br/pt/pdfs/rbac/rbac_40_02/08. pdf. Acesso em: 16 abr. 2014

SILVESTRE, F.A. Microbiota cervical anormal: diagnóstico e associação com fatores de risco, aspectos clínicos e citológicos. Universidade de Brasília. Brasília-DF 2016 (monografia) 67p.

SOARES M. B. O.; SILVA S.R. Resultados de citologia oncótica em uma regional de saúde no período de 2007-2008. Rev. Rene, Fortaleza, v. 11, p. 23-31, 2010. Disponível em: http://www.revistarene.ufc.br/edicaoespecial/a03v11esp_n4.pdf. Acesso em: 12 mar.2014

TAVARES, T. G. et al. Cervicites e seus agentes na rotina dos exames na rotina dos exames colpocitológicos. DST j. bras. doenças sex. transm., Rio de Janeiro, v. 9, n.1, p. 30-34, 2007. Disponivel em: http://www.dst. uff.br//revista19-1-2007/5.pdf. Acesso em: 12 mar. 2014.

UCHIMURA, N. S. et al. Avaliação da conduta conservadora na lesão intraepitelial cervical de alto grau. Rev. Saúde Pública, v. 46, n. 3, p. 466-471, 2012.

Submetido em: $31 / 05 / 2019$

Aceito em: 27/02/2019 